\title{
UNDERSTANDING MARKET REACTION TO COVID-19 MONETARY AND FISCAL STIMULUS IN MAJOR ASEAN COUNTRIES
}

\author{
Syed Aun Rizvi*, Solikin M. Juhro**, and Paresh Kumar Narayan*** \\ * Corresponding author. Lahore University of Management Science, Pakistan. \\ Email: aun.raza@lums.edu.pk \\ ** Bank Indonesia Institute, Bank Indonesia, Indonesia. Email: solikin@bi.go.id \\ *** Monash Business School, Monash University, Melbourne, Australia. \\ Email: pareshkumar.narayan@monash.edu.au
}

\begin{abstract}
In this paper, we examine the effect of fiscal and monetary policy stimulus actions during the COVID-19 pandemic on the stock markets of four ASEAN countries, namely, Indonesia, Singapore, Malaysia, and Thailand. Using time-series regression models, we show the relative importance of monetary and fiscal policies. Our findings suggest that 7-days after the policy announcement, fiscal policies helped cushion financial market losses in Indonesia, Singapore and Thailand. We do not find any robust evidence of policy effectiveness for Malaysia. While our investigation is preliminary it opens an additional avenue for understanding the effectiveness of policy stimulus.
\end{abstract}

Keywords: Stimulus; Fiscal policy; Monetary policy; Stock returns.

JEL Classifications: I18; E44; E52; E62.

\author{
Article history: \\ Received : April 02, 2021 \\ Revised : July 17, 2021 \\ Accepted : August 07, 2021 \\ Available Online : September 30, 2021 \\ https://doi.org/10.21098/bemp.v24i3.1690
}




\section{INTRODUCTION}

There is a growing literature on COVID-19 and its effects on financial markets in general. Many variants of the literature have evolved, investigating the role of the pandemic in shaping our financial and economic systems; surveys of the literature can be found in Padhan and Prabheesh (2021) and Narayan (2021). ${ }^{1}$ We connect to a sub-set of this literature that takes issue with the effectiveness of COVID-19 related policies (see, for instance, Narayan et al., 2021; Bannigidadmath et al., 2021). These studies have focused on lockdowns, travel bans or stimulus packages. An obvious research gap is that none of these studies has considered the relative importance of fiscal and monetary policy announcements during the pandemic on the reaction of financial markets. ${ }^{2}$

Our hypothesis is that financial markets would react heterogeneously to fiscal and monetary policy shocks depending of course on the severity of the policy announcement. Fiscal and monetary policies can also exert short term and medium term effects, again depending on the type of policy announcement. Therefore, a priori, the effect is unknown. The earlier literature on understanding policy announcements and their effect on equity markets suggests that central banks through their monetary policy actions influence the volatility of stock markets (see, for instance, Bomfim 2003; Lunde and Zebedee 2009; Papadamou et al., 2014). This effect unfolds via the investor risk-taking channel (Fassas and Papadamou, 2018). On the other hand, fiscal policies influence spending and signal fiscal policy intent, which shapes policy certainty/uncertainty. Policy certainty is factored in investor decision making, thus having an impact on share prices. The literature has established mixed evidences of the effect of fiscal policy announcements on stock prices (see, for instance, Afonso and Sousa, 2011, 2012; Hu et al., 2018).

From a financial market viewpoint, though, the key question is whether such policy announcements can help market recovery. Our hypothesis based on the above discussions is that policy announcements aid stock market recovery. In this paper, we propose to test this proposition, by estimating a risk factor model-a model that accounts for all conventional market risks - and comparing the resulting abnormal returns (if any) with augmented risk factor models that include policy announcements.

Our finding is that fiscal policy is more effective. That is, in a horse race between fiscal policy and monetary policy announcements, we discover that it is fiscal policies in at least three countries (Indonesia, Singapore and Thailand) that have aided the recovery of stock markets. We were unable to discover robust evidence of the effectiveness of policy announcements for Malaysia.

Our study makes two contributions. First, we are the first to document the relationship between policy announcements and stock market returns during the pandemic. We were able to distinguish the role of fiscal policies from monetary

\footnotetext{
1 There are now several special issues on the COVID-19 pandemic; we refer interested readers to the special issues of Sha and Sharma (2020) and Sharma and Sha (2020) as they cover a wide range of economics and finance topics.

2 In responding to the impact of the COVID-19 pandemic, authorities in various countries introduced and implemented extraordinary measures to mitigate the effects of the pandemic. The main fiscal policy response was economic stimulus at least in countries that had the fiscal space to accommodate this policy.
} 
policies during the COVID-19 period and showed that when viewed over a short horizon; that is, 7-days post-announcements - fiscal policies are more effective in stock market recovery than monetary policies. One implication is that monetary policy may take a longer time to take effect. Empirically, compared to monetary policy, fiscal policy transmission operates through more varied instruments and mechanisms, with a more direct and selective impact on household income and firm profitability. The difference between fiscal and monetary policies was clearly seen during the COVID-19 crisis. However, although monetary and fiscal policies both contribute as independent tools for economic stabilization, their effects on the economy are generally interrelated. Therefore, coordination of fiscal and monetary policies is urgently needed so that their impact on growth, inflation, and financial stability can be optimized.

Second, our findings add to understanding the behavior of Asian financial markets during the COVID-19 pandemic (see, for instance, Devpura, 2020; Bing, 2021; Yang and Deng, 2021; Gil-Alana, and Claudio-Quiroga, 2020; Sharma, 2020). As much as we contribute to the literature, our study has limitations too which we address in Section IV. The remainder of the paper proceeds as follows. Section II explains data and methodology. Section III has the results while the final section concludes.

\section{DATA AND METHODOLOGY}

In this study, we employ time-series daily data for the period February 28, 2020 to March 17, 2021 ${ }^{3}$. Our sample of countries includes four major ASEAN member countries, namely Indonesia, Malaysia, Singapore and Thailand ${ }^{4}$. The equity benchmark indices used are the primary indices reported by stock exchanges namely, the Jakarta Stock Exchange Composite Index, the FTSE Bursa Malaysia KLCI Index, the Strait Times Index and the Stock Exchange of Thailand SET Index. All these indices are obtained from Bloomberg.

To understand the response of markets to major economic stimulus, we collect dates when the countries announced fiscal and monetary policy measures to spur growth and mitigate the negative repercussions of the pandemic. The data are sourced through Bloomberg and cross-verified from each country's central bank and economic/finance Ministry's official announcement database. To summarize this data, the Indonesian, Malaysian, Singaporean and Thai policy makers made around 26, 21, 8, and 17 policy announcements, respectively (Details of these announcements are provided in Appendix). From these policy announcements, we filtered for substantial announcements based on where changes in monetary or fiscal measures were undertaken and removed announcements which related

\footnotetext{
3 The date range is based on availability of data of policy announcements, which coincided with the severity of the pandemic in the ASEAN region.

4 The ASEAN region has a sizeable population of 640 million with economic growth in excess of $5 \%$ in last decade which is estimated by the Asian Development Bank to recover post-pandemic to $7.7 \%$ growth in 2021. Based on the IMF data, the four ASEAN countries in our sample have a total nominal GDP contribution of 73 percent, while each country has a nominal GDP per capita of over 4,000 USD, which is roughly equivalent to the lowest reference figure for the upper-middle income group of countries.
} 
to non-quantitative actions. This resulted in 10, 9, 7 and 10 measures for Indonesia, Malaysia, Singapore and Thailand, respectively. The number of fiscal and monetary measures taken by each government is summarized in Table 1.

Table 1.

Government Stimulus Details

The following table provides the number of stimulus actions taken by each country's policy makers. They are further segregated into fiscal and monetary policies.

\begin{tabular}{lccc}
\hline & Total Stimulus & Fiscal & Monetary \\
\hline Indonesia & 10 & 4 & 6 \\
Malaysia & 9 & 4 & 5 \\
Singapore & 7 & 5 & 2 \\
Thailand & 10 & 4 & 6 \\
\hline
\end{tabular}

To understand the volatility of stock markets following the works of Haroon et al. (2021), Yu and Hassan (2008), Rizvi et al. (2018), we employ an exponential GARCH model. The literature suggests reliance on asymmetric GARCH model developed by Nelson (1991):

$$
\ln \sigma_{j, t}^{2}=\omega_{t}+\beta_{j} \ln \left(\sigma_{j, t-1)}^{2}+\gamma \frac{\varepsilon_{t-1}}{\sqrt{\sigma_{t-1}^{2}}}+\alpha\left[\frac{\left|\varepsilon_{t-1}\right|}{\sqrt{\sigma_{t-1}^{2}}}-\sqrt{\frac{2}{\pi}}\right]\right.
$$

where $\sigma_{j, t}^{2}$ denotes the conditional variance since it is a one-period ahead estimate for the variance calculated on any past relevant information. In represents natural logarithm, $\omega_{t}$ symbolizes a conditional density function. The $\alpha$ consideration represents the symmetric effect of the model, i.e. the GARCH effect and $\beta$ calculates the perseverance in conditional volatility irrespective of market movements. Furthermore, the parameter $\gamma$ measures the leveraging effect.

For understanding the response of equity markets to these measures, we use an event study framework similar to the recent work of Yan and Qian (2020), who studied the Chinese stock market reaction to COVID-19. With the limitation of data and focus on understanding the short-term reaction, event study methods are reliable for short-horizon as investigated by Kothari and Warner (2007). We use two window lengths of 3-days and 7-days to explore the behaviour of returns and volatility to understand the response of ASEAN financial markets.

\section{RESULTS}

Tables 2 and 3 present the average returns and volatility of equity markets in the ASEAN countries 3-days and 7-days post stimulus announcement by policy makers. The evidence exhibits interesting insights: Amongst the four ASEAN countries, Indonesia and Singapore had higher negative returns immediately after the stimulus announcement compared to the full sample average. Interestingly, the 7-day response is more negative for fiscal than monetary announcements for 
Indonesia. For Malaysia, fiscal policies seem more effective and while both fiscal and monetary policy announcements positively influence Thailand's stock market returns, the effect of monetary policy announcements is stronger. Focusing on aggregate policy announcements, the post 7-day impact is positive for Malaysia and Thailand and negative for Indonesia and Singapore.

Table 2.

\section{Average Daily Returns}

This table presents the average daily returns of the benchmark stock indices for Indonesia, Malaysia, Singapore and Thailand. Column 1 presents the average returns over the full sample period, from February 2, 2020 to March 17, 2021. Columns 2 and 3 present the average returns in 7-day and 3-day windows of economic stimulus announcements. Columns 4 and 5 show the average returns of the market on a 7-day window for economic stimulus announcements segregated by fiscal and monetary policies. Columns 6 and 7 present the segregated average returns the for 3-day window.

\begin{tabular}{lccccccc}
\hline & & & & \multicolumn{2}{c}{ 7-day Window } & \multicolumn{2}{c}{ 3-day Window } \\
\cline { 5 - 8 } & Full & 7-day & 3-day & Fiscal & Monetary & \multirow{2}{*}{ Fiscal } & \multirow{2}{*}{ Monetary } \\
\hline Sample & & & & & & \\
\hline Indonesia & $-0.04 \%$ & $-0.69 \%$ & $-0.45 \%$ & $-1.72 \%$ & $-0.01 \%$ & $-1.14 \%$ & $0.01 \%$ \\
Malaysia & $0.05 \%$ & $0.24 \%$ & $0.51 \%$ & $0.67 \%$ & $-0.20 \%$ & $0.79 \%$ & $0.23 \%$ \\
Singapore & $0.02 \%$ & $-0.18 \%$ & $-0.18 \%$ & $-0.09 \%$ & $-0.34 \%$ & $-0.22 \%$ & $-0.20 \%$ \\
Thailand & $0.01 \%$ & $0.35 \%$ & $0.18 \%$ & $0.35 \%$ & $0.52 \%$ & $-0.31 \%$ & $0.26 \%$ \\
\hline
\end{tabular}

Table 3.

\section{Average Volatility}

This table presents the average volatility of Benchmark Stock Indices for Indonesia, Malaysia, Singapore and Thailand. Column 1 presents the average volatility over the full sample period, from February 2, 2020 to March 17, 2021. Columns 2 and 3 present the average returns in 7-day and 3-day windows of economic stimulus announcements. Columns 4 and 5 show the average volatility of the market on a 7-day window for economic stimulus announcements segregated by fiscal and monetary policies. Columns 6 and 7 present the segregated average volatility the for 3-day window.

\begin{tabular}{lccccccc}
\hline & & & \multicolumn{2}{c}{ 7-day Window } & \multicolumn{2}{c}{ 3-day Window } \\
\hline & $\begin{array}{c}\text { Full } \\
\text { Sample }\end{array}$ & 7-day & 3-day & Fiscal & Monetary & Fiscal & Monetary \\
\hline Indonesia & $1.83 \%$ & $2.39 \%$ & $2.38 \%$ & $2.99 \%$ & $1.98 \%$ & $2.99 \%$ & $1.98 \%$ \\
Malaysia & $1.38 \%$ & $1.81 \%$ & $1.78 \%$ & $1.81 \%$ & $1.76 \%$ & $1.81 \%$ & $1.76 \%$ \\
Singapore & $1.56 \%$ & $1.73 \%$ & $1.78 \%$ & $1.47 \%$ & $2.47 \%$ & $1.47 \%$ & $2.47 \%$ \\
Thailand & $1.82 \%$ & $2.39 \%$ & $2.50 \%$ & $3.04 \%$ & $2.31 \%$ & $3.04 \%$ & $2.31 \%$ \\
\hline
\end{tabular}

When disaggregating policy announcements, the 7-day response sees fiscal policy more effective in Malaysia and Singapore while monetary policy is more effective in Indonesia and Thailand. Table 3 reports the effect of announcements on stock market volatility. Both the 3-day and 7-day post-announcement sees monetary policy having a lesser effect on volatility than fiscal policy in three out of the four countries. The exception is Singapore. The implication here is that fiscal policy has created greater volatility in the market.

To further analyze whether announcements significantly impacted the stock market returns, we use an ordinary least squares regression model that corrects 
for heteroskedasticity using the Newey and West (1987) approach, where optimal lag lengths are selected using the Akaike Information Criterion beginning with a maximum of 3 lags. The model has the following specification:

$$
S t_{t}=\alpha+\beta_{1} M K T_{t}+\beta_{2} S M B_{t}+\beta_{3} H M L_{t}+\beta_{4} D a y+\beta_{5} S t i+\varepsilon
$$

where, $M K T_{t}$ is the excess market return, $S M B_{t}$ is the small-minus-big firm size premium, $H M L_{t}$ is the high-minus-low book-to-market value premium ${ }^{5}$, Day is a dummy variable capturing day-of-the week effects for Monday, Tuesday, Thursday and Friday, and Sti is the dummy for stimulus, taking a value one on days of stimulus and a value of zero otherwise. This dummy is split into fiscal and monetary policy dummies.

Tables 4-7 present the regression results for multiple models for each country. We engage with multiple models at the outset because it allows us to judge robustness of the effect of fiscal and monetary policy announcements simultaneously. The results are as follows. Starting with Indonesia, we see that abnormal losses (that is, losses recorded after all market risk factors have been accounted for) without the announcement effect was valued at $4.02 \%$ per annum $(t=2.71)$. The post-7-days after the announcement, abnormal losses were reduced to $3.83 \%$ per annum $(t=2.91)$. Fiscal stimulus alone was responsible for reducing abnormal losses to $3.38 \%$ per annum $(t=-2.99)$. In the case of Malaysia, the 7 -day post announcement effect is statistically significant at the $10 \%$ level with a $0.0034 \%$ effect on returns. There is no robust effect, neither from policy announcements directly nor indirectly from abnormal returns. For Singapore, we see that without the announcement (Model 1), abnormal losses were $2.43 \%$ per annum $(t=-2.17)$; however, as the policy was introduced, market losses disappeared as all abnormal returns are statistically zero. Finally, for Thailand, the abnormal loss without announcement is recorded at $3.16 \%(t=-2.43)$ which was higher with the 7 -day post-monetary policy announcement at 3.30\% $(t=-2.68)$ but recorded lowest with fiscal policy announcement at $2.48 \%(t=-2.53)$.

5 The data for risk free rate for excess return calculation and size and value premium have been sourced from Kenneth R French library available at https://mba.tuck.dartmouth.edu/pages/faculty/ ken.french/data_library.html 


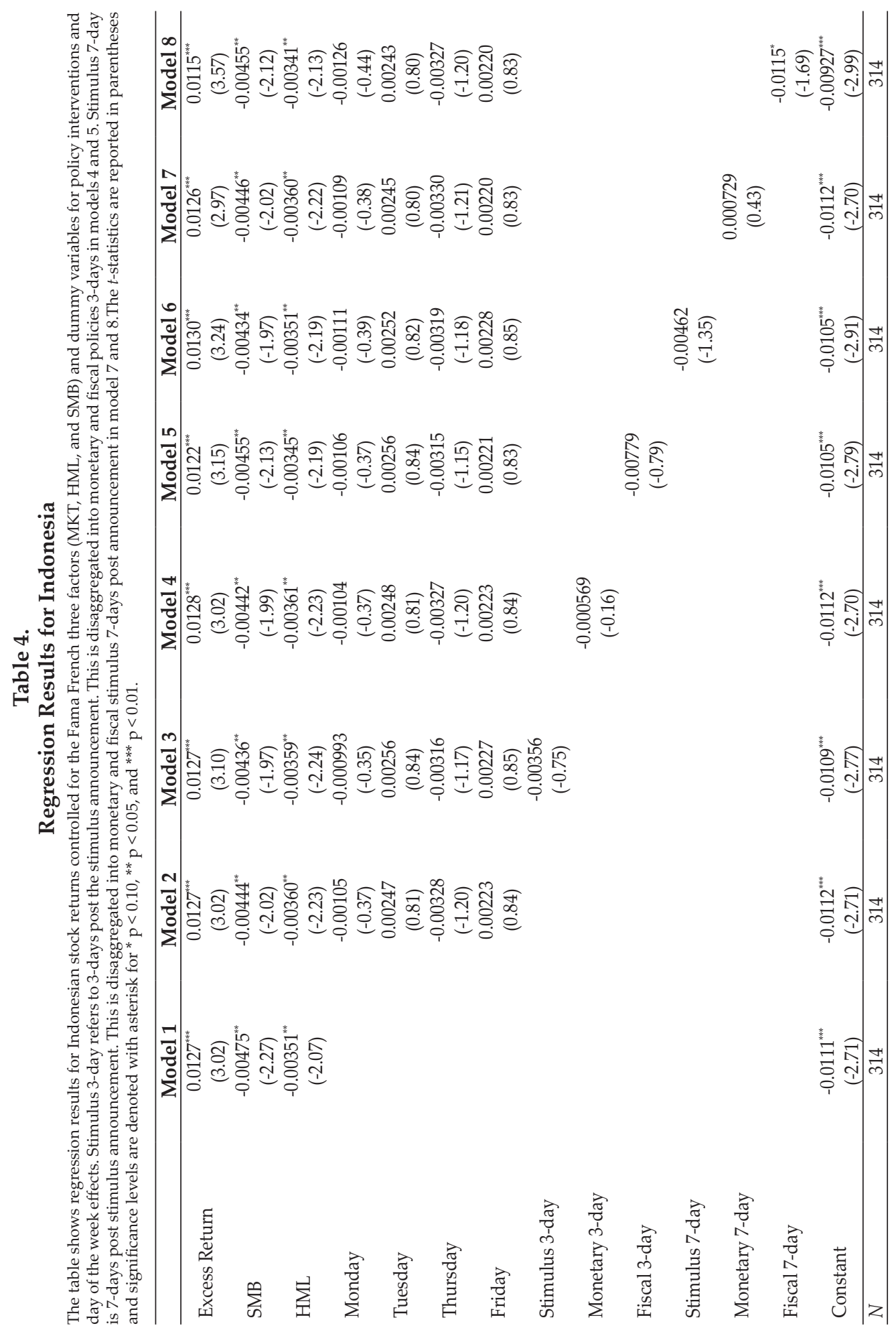




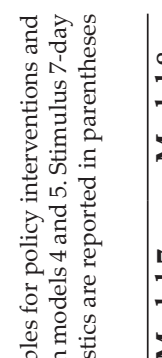

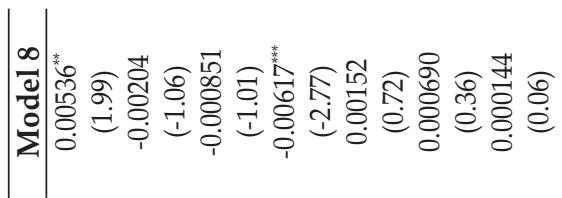

웜

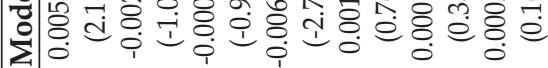

올.

$>$ 要

है

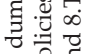

표

चี $\frac{\mathrm{d}}{\mathrm{d}}$

$\sum_{0}^{\infty}$

조

政艺

$\sum$

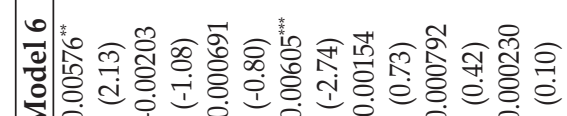

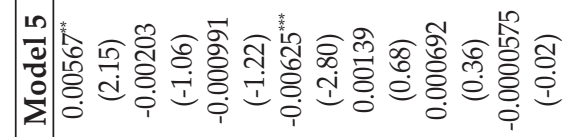

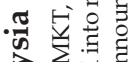

至

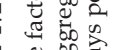

ț

in

党

농

पू

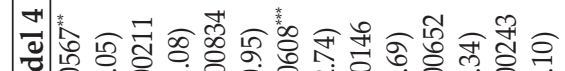

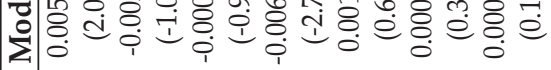

ิㅗㅅ

ठิ.

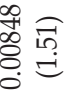

웡

灾

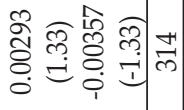

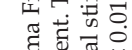

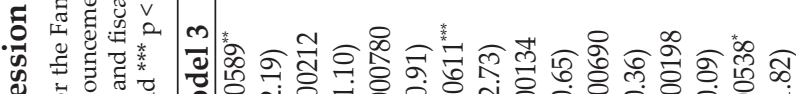

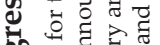

o t 등

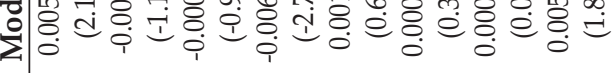

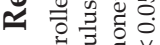

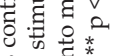

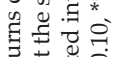

范范住

$\checkmark$ के

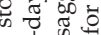

ㄷำ के

की

$\sum^{\pi}$

逑苟责

के के चु

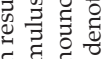

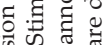

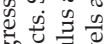

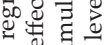

造娄

क苛范

욜

उ

点胥包

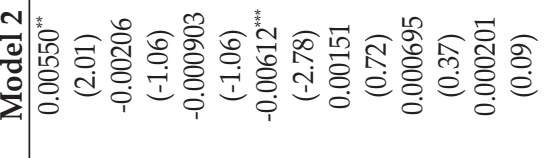

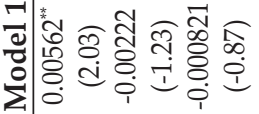

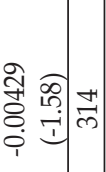

容

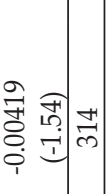

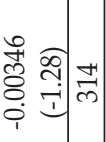

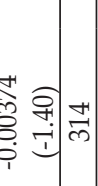

通递 


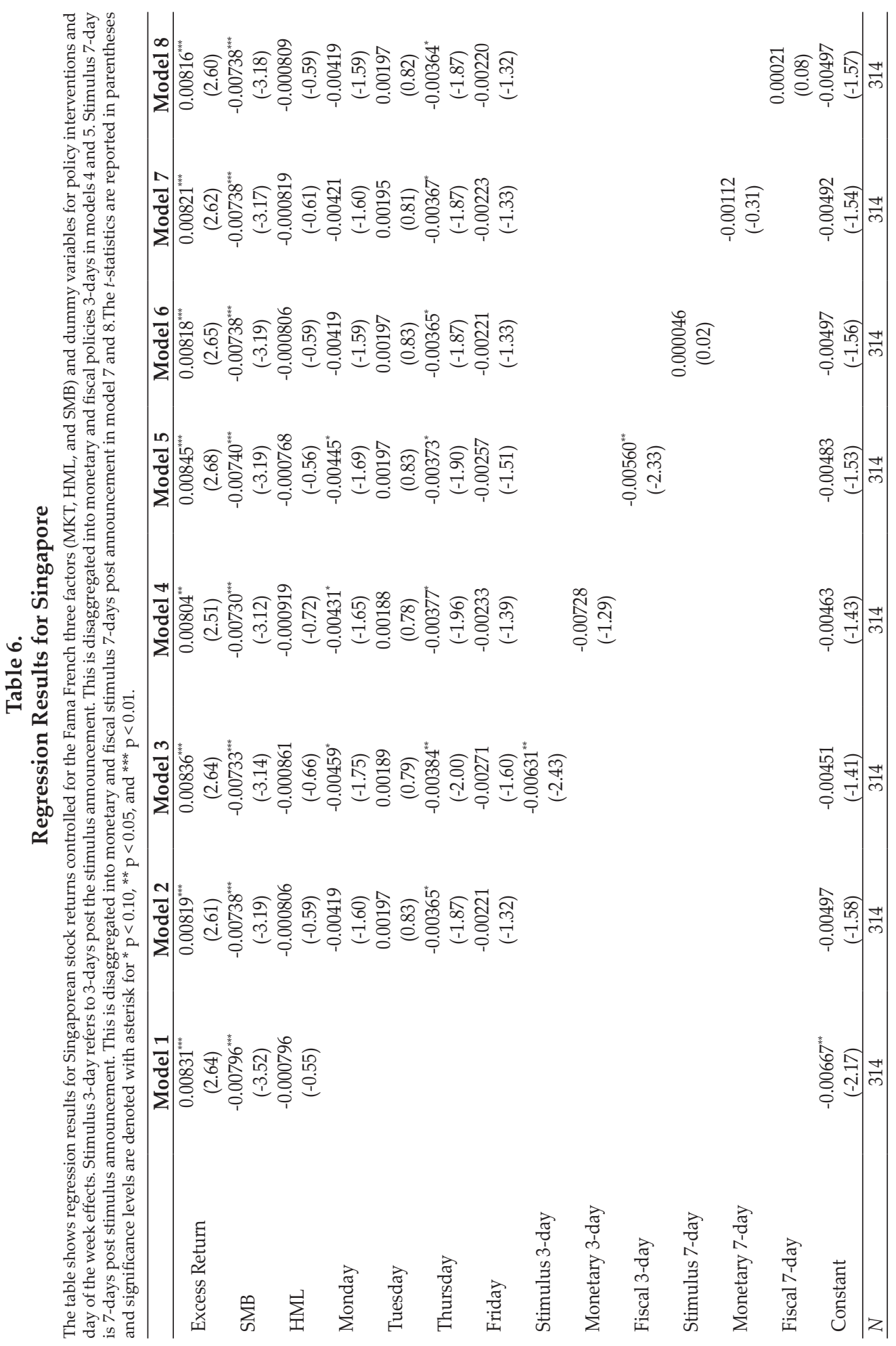




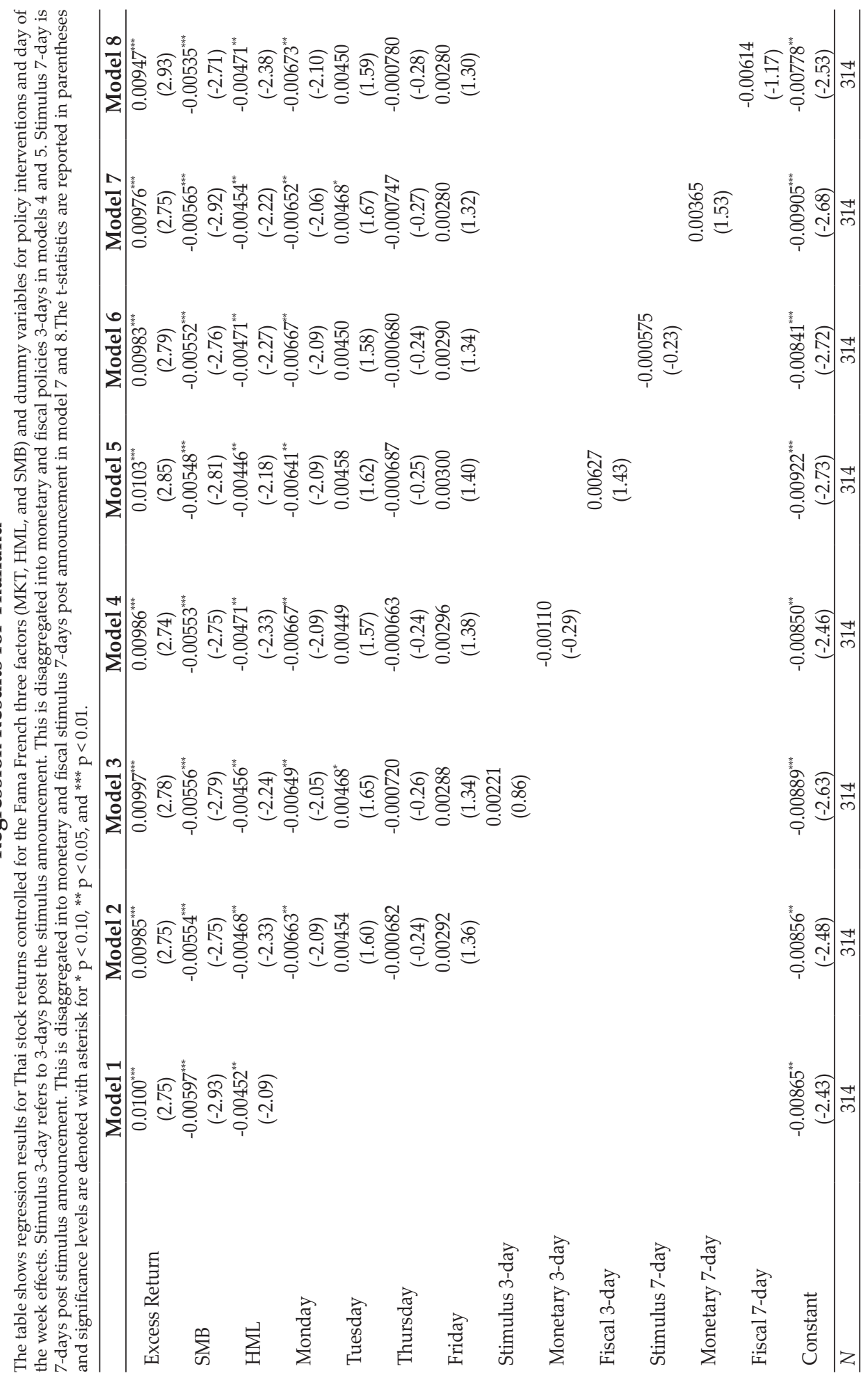




\section{CONCLUDING REMARKS}

In this paper, we investigate the specific roles of monetary and fiscal policy announcements in response to the COVID-19 pandemic on stock markets of Indonesia, Singapore, Malaysia and Thailand. Our hypothesis is that financial markets would react heterogeneously to fiscal and monetary policy shocks depending on the policy announcement. Fiscal and monetary policies can also exert short term and medium term effects again depending on the type of policy announcement. Therefore, a priori, the effect is unknown. We put to test our hypothesis by estimating a market risk factor model that is augmented with policy announcement effects. To judge the effectiveness or importance of fiscal and monetary policy announcements, we compare abnormal returns from the market risk adjusted model with and without those announcements. Our finding is that fiscal policy is more effective. That is, in a horse race between fiscal policy and monetary policy announcements, we discover that it is fiscal policies in at least three countries (Indonesia, Singapore and Thailand) that have aided the recovery of stock markets immediately. We were unable to discover robust evidence of the effectiveness of policy announcements for Malaysia.

That monetary policy is less effective could simply mean that it will take more time for such policy announcements to effect stock returns, contrasting earlier findings of Lunde and Zebedee (2009), Papadamou et al. (2014) and Fassas and Papadamou (2018). To put our findings into perspective, we should not ignore the fact that the policy of providing stimulus (fiscal policy) in various countries is generally carried out in a coordinated policy manner at the national level. In this context, one important strategy to be taken is to synchronize the timing of the implementation of various policies in overcoming supply-demand expectations. By its nature, in the short term (immediate) fiscal stimulus is expected to play a key role in responding to pressures on the demand side, with the expectation that improvements on the supply side will follow. Furthermore, it is hoped that monetary stimulus, which is generally transmitted through the financial sector first, will work to boost the real sector. We set aside this as an agenda for future research.

Considering the complexity of the problem and the nature of the different fiscal and monetary policy responses, the above findings imply the increasing importance of strengthening communication strategies during the pandemic crisis. Effective and 'balanced' communication by policy making authorities is essential in managing the credibility of a policy stance, apart from increasing transparency. Although there is no standard approach on how well the communication strategy is implemented, strong communication, which reflects the attention and appropriate response from fiscal and monetary policy authorities, is important to correct financial market perceptions about policy uncertainty. This overall message of our work is consistent with the message in Smales and Apergis (2017): that the language of communication and interpretation by policy makers is becoming more critical in terms of its impact on financial markets.

In closing, we acknowledge that our work is preliminary. We do not address all matters relating to policy effectiveness in this pandemic because it is impossible to do so. One limitation of our work relates to data on policy announcements. In making a start on this line of research, we used the number of announcements 
made. This does not capture the intensity of announcements and the possibility of pre-emptive reaction of market players to announcements made by monetary and fiscal authorities. Herein, we believe, lies the role of future research. Future studies can consider alternative measures and proxies for capturing these policy announcements. The main takeaway from our paper is the need to understand the role of monetary and policy policies when faced by global crises. In this regard, our paper sets the motivation for future research, so we hope.

Acknowledgement: An earlier version of this paper was presented on July 2, 2021 at the International Economic Association Online World Congress on the theme "COVID-19 and Monetary Policy". This session was sponsored by Bank Indonesia and jointly organised by Bank Indonesia and the Asia-Pacific Applied Economics Association. Helpful comments and suggestions from conference participants and two reviewers of BMEB are duly acknowledged.

\section{REFERENCES}

Afonso, A., \& Sousa, R. M. (2011). What are the Effects of Fiscal Policy on Asset Markets? Economic Modelling, 28, 1871-1890.

Afonso, A., \& Sousa, R. M. (2012). The Macroeconomic Effects of Fiscal Policy. Applied Economics, 44, 4439-4454.

Bannigidadmath, D., Narayan, P. K., Phan, D. H. B., \& Gong, Q. (2021). How Stock Markets Reacted to COVID-19? Evidence from 25 Countries. Finance Research Letters, 102161.

Bing, T. (2021). The Impact of COVID-19 on the Relation Between Retail Investors' Trading and Stock Returns in the Chinese Market. Asian Economics Letters, 2, 19015. https://doi.org/10.46557/001c.19015

Bomfim, A. N. (2003). Pre-announcement Effects, News Effects, and Volatility: Monetary Policy and the Stock Market. Journal of Banking E Finance, 27, 133151.

Devpura, N. (2020). Can Oil Prices Predict Japanese Yen? Asian Economics Letters, 1, 17964. https://doi.org/10.46557/001c.17964

Fassas, A. P., \& Papadamou, S. (2018). Unconventional Monetary Policy Announcements and Risk Aversion: Evidence from the US and European Equity Markets. The European Journal of Finance, 24, 1885-1901.

Gil-Alana, L. A., \& Claudio-Quiroga, G. (2020). The COVID-19 Impact on the Asian Stock Markets. Asian Economics Letters, 1, 17656. https://doi.org/10.46557/001c.17656

Haroon, O., Ali, M., Khan, A., Khattak, M. A., \& Rizvi, S. A. R. (2021). Financial Market Risks during the COVID-19 Pandemic. Emerging Markets Finance and Trade, 57, 2407-2414.

Hu, L., Han, J., \& Zhang, Q. (2018). The Impact of Monetary and Fiscal Policy Shocks on Stock Markets: Evidence from China. Emerging Markets Finance and Trade, 54, 1856-1871.

Kothari, S. P., \& Warner, J. B. (2007). Econometrics of Event Studies. In Handbook of Empirical Corporate Finance (3-36). Elsevier. 
Lunde, A., \& Zebedee, A. A. (2009). Intraday Volatility Responses to Monetary Policy Events. Financial Markets and Portfolio Management, 23, 383-399.

Narayan, P. K. (2021) COVID-19 Research Outcomes: An Agenda for Future Research, Economic Analysis and Policy, 71, 439-445.

Narayan, P. K., Phan, D. H. B., \& Liu, G. (2021). COVID-19 Lockdowns, Stimulus Packages, Travel Bans, and Stock Returns. Finance Research Letters, 38, 101732.

Nelson, D. B. (1991). Conditional Heteroskedasticity in Asset Returns: A New Approach. Econometrica: Journal of the Econometric Society, 347-370.

Newey, W. K., \& West, K. D. (1987). A Simple, Positive Definite, Heteroskedastic and Autocorrelation Consistent Covariance Matrix. Econometrica, 55, 703-708

Padhan, R., \& Prabheesh, K. P. (2021). The Economics of COVID-19 Pandemic: A Survey. Economic Analysis and Policy, 70, 220-237.

Papadamou, S., Sidiropoulos, M., \& Spyromitros, E. (2014). Does Central Bank Transparency Affect Stock Market Volatility? Journal of International Financial Markets, Institutions and Money, 31, 362-377.

Rizvi, S. A. R., Arshad, S., \& Alam, N. (2018). A Tripartite Inquiry into Volatilityeffeciency-intergration Nexus-case of Emerging Markets. Emerging Markets Review, 34, 143-161.

Sha, Y., \& Sharma, S. S. (2020). Research on Pandemics Special Issue of the Journal Emerging Markets Finance and Trade. Emerging Markets Finance and Trade, 57.

Sharma, S. S. (2020). A Note on the Asian Market Volatility during the COVID-19 Pandemic. Asian Economics Letters, 1, 17661. https://doi.org/10.46557/001c.17661

Sharma, S. S., \& Sha, Y. (2020). Part A: Special Section on COVID-19 Research. Emerging Markets Finance and Trade, 56.

Smales, L. A., \& Apergis, N. (2017). Understanding the Impact of Monetary Policy Announcements: The Importance of Language and Surprises. Journal of Banking \& Finance, 80, 33-50.

Yan, L., \& Qian, Y. (2020). The Impact of COVID-19 on the Chinese Stock Market: An Event Study based on the Consumer Industry. Asian Economics Letters, 1, 18068. https://doi.org/10.46557/001c.18068

Yang, H., \& Deng, P. (2021). The Impact of COVID-19 and Government Intervention on Stock Markets of OECD Countries. Asian Economics Letters, 1, 18646. https://doi.org/10.46557/001c.18646

Yu, J. S., \& Hassan, M. K. (2008). Global and Regional Integration of the Middle East and North African (MENA) Stock Markets. The Quarterly Review of Economics and Finance, 48, 482-504. 


\section{APPENDIX \\ ASEAN Countries Announcements of Fiscal and Monetry Policies}

The following tables provide the details of all policy (monetary \& fiscal) announcements made by Indonesia, Malaysia, Singapore and Thailand from January 1, 2020 till March 31, 2021.

Table A.1.

Indonesia

\begin{tabular}{|c|c|c|}
\hline No & Date & Announcement \\
\hline 1 & 24-Jan-20 & $\begin{array}{l}\text { The BI Board of Governors agreed to hold the BI 7-Day Reverse Repo (BI- } \\
\text { 7DRR) rate at 5.00\%, while also maintaining the Deposit Facility (DF) and } \\
\text { Lending Facility (LF) rates at } 4.25 \% \text { and } 5.75 \% \text {. }\end{array}$ \\
\hline 2 & 10-Mar-20 & $\begin{array}{l}\text { On February 25, 2020, the Indonesian government unveiled a US\$725 million } \\
\text { stimulus package to support the tourism, airline, and the property industries } \\
\text { in the wake of the Covid-19 outbreak. In addition, local governments will be } \\
\text { compensated by the central government for the loss of taxes which is estimated } \\
\text { to total US } \$ 230 \text { million. The government prepared funding totaling } 4.6 \text { trillion } \\
\text { rupiah (US } \$ 324 \text { million) for the Affordable Food Program to boost local } \\
\text { consumption and help } 15 \text { million low-income households buy staple foods. } \\
\text { As part of this stimulus package, low-income households will also receive } \\
\text { US\$13.97 per month in financial benefits, an increase from US } \$ 10 \text { for the next } \\
\text { six months. }\end{array}$ \\
\hline 3 & 13-Mar-20 & $\begin{array}{l}\text { The Indonesian government issued its second emergency stimulus package } \\
\text { worth US } \$ 8 \text { billion. The latest package represents } 0.8 \% \text { of the GDP and } \\
\text { provides a range of fiscal and non-fiscal incentives in addition to a special } \\
\text { stimulus for SMEs businesses. Additionally, SMEs are eligible for loans up to } 10 \\
\text { billion rupiah (US\$655,000) if they have a good credit history. }\end{array}$ \\
\hline 4 & 31-Mar-20 & $\begin{array}{c}\text { The government issued a Regulation No.1/2020 (Perppu No.1/2020) as a legal } \\
\text { basis to overcome the crunch conditions that forced the anticipatory measures } \\
\text { and extraordinary. With Perppu 1/2020, the Government has the flexibility } \\
\text { to allocate additonal expenditure, financing, and widen the budget (APBN) } \\
\text { defeicit more than 3\%. }\end{array}$ \\
\hline 5 & 06-Apr-20 & $\begin{array}{l}\text { The BI Board of Governors agreed on 18th and 19th March } 2020 \text { to lower } \\
\text { the BI-7DRR by } 25 \text { bps to } 4.50 \% \text {, DF rates lowered } 25 \text { bps } 3.75 \% \text { and LF rates } \\
\text { lowered } 25 \text { bps to } 5.25 \% \text {. Expanding the incentive of a } 50 \mathrm{bps} \text { daily rupiah } \\
\text { reserve requirement beyond banks that are engaged in export-import financing } \\
\text { to include the financing of MSMEs. }\end{array}$ \\
\hline 6 & 15-Apr-20 & $\begin{array}{l}\text { The BI Board of Governors agreed on 13th and 14th April } 2020 \text { to hold the BI- } \\
\text { 7DRR at 4.50\%, while also maintaining the DF and LF rates at 3.75\% and 5.25\%. } \\
\text { BI lower the rupiah reserve requirement ratios and raised the Macroprudential } \\
\text { Liquidity Buffer (MLB) by 200bps for conventional commercial banks and by } \\
\text { 50bps for Islamic banks/Islamic business units, effective from May 1, 2020. }\end{array}$ \\
\hline 7 & 30-Apr-20 & $\begin{array}{l}\text { Indonesia will be extending its tax incentives (rolled out in the second stimulus } \\
\text { package) to cover more business sectors. The second stimulus package was set } \\
\text { out in the Ministry of Finance Regulation } 23 \text { of } 2020 \text { (Reg 23/2020) and provide } \\
\text { some US } \$ 1.4 \text { billion worth of tax breaks. The government expects this tax break } \\
\text { to cost } 35.5 \text { trillion rupiah (US } \$ 2.3 \text { billion) and cover } 18 \text { additional sectors. }\end{array}$ \\
\hline 8 & 11-May-20 & Perppu No.1/2020 was later passed into Act (UU) No.2 of 2020. \\
\hline 9 & 20-May-20 & $\begin{array}{l}\text { On May 11, 2020, the Indonesian government issued Reg 23/2020 on the } \\
\text { implementation of the National Economic Recovery (NER) program. The } \\
\text { program is estimated to cost US } \$ 43 \text { billion and comprises of tax breaks for } \\
\text { industries, capital injections to state-owned companies, and liquidity support } \\
\text { for the banking industry. With the launch of the program, the country's budget } \\
\text { deficit is expected to reach } 6.7 \% \text { of GDP in } 2020 \text {. }\end{array}$ \\
\hline
\end{tabular}




\begin{tabular}{|c|c|c|}
\hline No & Date & Announcement \\
\hline 10 & 19-Jun-20 & $\begin{array}{l}\text { The BI Board of Governors agreed on the } 17 \text { th and } 18 \text { th June } 2020 \text { to lower the } \\
\text { BI-7DRR by } 25 \text { bps to } 4.25 \% \text {, DF rates lowered } 25 \text { bps to } 3.50 \% \text { and LF rates } \\
\text { lowered } 25 \text { bps to } 5.00 \% \text {. }\end{array}$ \\
\hline 11 & 25-Jun-20 & $\begin{array}{l}\text { Indonesia's Ministry of Finance issued implementing Regulation 65/2020, } \\
\text { which addresses the criteria for which MSMEs can receive interest subsidies. } \\
\text { Under Reg65/2020, eligible businesses can receive interest subsidies of between } \\
\text { two to six percent. The program is part of the government's US } \$ 45 \text { billion NER, } \\
\text { which aims to mitigate the impact of the pandemic through tax break and other } \\
\text { incentives. }\end{array}$ \\
\hline 12 & 02-Jul-20 & $\begin{array}{c}\text { On June 23, 2020, Indonesia's Ministry of Finance issued implementing } \\
\text { Regulation 71/PMK.08/2020 (Reg 71/2020), which appointed state-owned } \\
\text { insurance providers Askrindo and Jamkrindo, to provide guarantees for banks } \\
\text { providing working capital loans MSMEs. Askrindo and Jamkrind received } \\
\text { some } 6 \text { tirllion rupiah (US\$408 million) to carry out this incentive. To further } \\
\text { boost channeling loans to MSMEs, the government injected } 30 \text { trillion rupiah } \\
\text { (US\$2 billion) to state-owned banks and has allocated } 35 \text { trillion rupiah (US\$2.4 } \\
\text { billion) interest subsidies. }\end{array}$ \\
\hline 13 & 17-Jul-20 & $\begin{array}{l}\text { The BI Board of Governors agreed on the 17th and 18th June } 2020 \text { to lower the } \\
\text { BI-7DRR by } 25 \text { bps to } 4.00 \% \text {, DF rates lowered } 25 \text { bps to } 3.25 \% \text { and LF rates } \\
\text { lowered } 25 \text { bps to } 4.75 \% \text {. }\end{array}$ \\
\hline 14 & 05-Aug-20 & $\begin{array}{c}\text { In terms of fiscal management, the government has increased fiscal capacity } \\
\text { in the context of handling Covid-19 outbreak by widening the } 2020 \text { state } \\
\text { budget deficit as a countercyclical strategy, from } 1.76 \% \text { of GDP to } 5.07 \% \\
\text { (Perpres 54/2020) and 6.34\% (Perpres 72/2020). Through ths deficit widening, } \\
\text { the government has allocated a budget for handling Covid-19 outbreak for } \\
\text { Rp695.20 trillion. }\end{array}$ \\
\hline
\end{tabular}

BI continues its commitment to funding the 2020 state budget through government bonds $(\mathrm{SBN})$ purchases in the primary market in accordance with Act No.2/2020 through market mechanisms and private placements as part of the efforts to accelerate the NER program, while maintaining macroeconomic 15 28-Aug-20 stability. As of 18th August 2020, BI had purchased Rp42.96 trillion of SBN in the primary market (Joint Decree on 16 April 2020). Meanwhile, SBN purchases by $\mathrm{BI}$ in the primary market through private placements based on Joint Decree of the Minister of Finance and Governor of BI issued on 7th July 2020 currently total Rp82.1 trillion.

Indonesia's Minister of Manpower issued Regulation 14 of 2020 (Reg 14/2020) on August 14, 2020, which introduces a new wage subsidy program for selected employees in Indonesia's private sector. Eligible employees will receive a total of 2.4 million rupiah (US\$164), disbursed over four months, divided by payments of 1.2 million rupiah (US\$82) every two months. The incentive is available to employees with a monthly income of less than 5 million rupiah (US\$342) and are registered and active with the Social Security Administration Body for Employment (BPJS Ketenagakerjaan).

In terms of fiscal management, the 2020 state budget has implemented an effective countercyclical function in the second quarter of 2020, as indicated by the APBN deficit until the end of the third quarter of 2020 which reach Rp682.1 tirllion of $4.16 \%$ of GDP. Realisation of state revenue amounted to Rp1,159.0 tirllion or $68.2 \%$ of the target in Perpres (President Decree) No.72/2020 or grew negatively by $13.7 \%$ (yoy), in line with slowing economic activity and increasing tax stimulus. Realisation of government expenditures accelerated in the third quarter of 2020 with grow of $15.5 \%$ (yoy), reaching Rp1,841.1 trillion or $67.2 \%$

of the budget. Expenditures increased sharply on the NER program and accelerated the distribution of Transfers to Regions and Village Funds (TKDD). 


\begin{tabular}{lcc}
\hline No & Date & Announcement \\
\hline 18 & OJK remains focused on strengthening integrated supervision to be able to \\
detect potential risks in Financial System Stability and continues to mitigate it \\
with countercyclical policies to assist in the recovery of the real sector and the \\
economy as a whole. The credit restructuring program in the baking sector as \\
of 28th September 2020 reached Rp904.3 trillion for 7.5 million debtors and in \\
finance companies as of 29th September 2020 it reached Rp107.17 trillion for 4.6 \\
million contracts.
\end{tabular}

As of December 23, 2020, the realisation of the NER program had reached Rp502.71 trillion or equivalent to $72.3 \%$ of the total budget at Rp695.2 trillion.

$21 \quad 30-$ Dec-20 Two clusters in the NER program recorded an achievement of more than $90 \%$, namely the social protection cluster which reached $94.7 \%$ or Rp217.99 trillioun; and the MSMEs cluster which achieved realisation of $92.8 \%$ or Rp107.93 trillion of the budget allocation amounting to Rp116.31 trillion.

The realisation of the NER program in 2020 has absorbed Rp579.8 trillion or $84.4 \%$ of the total budget. The performance of the state budget as a countercyclical tool to respond the impact of Covid-19 pandemic until the end 22 27-Jan-21 of 2020 is quite controlled while maintaining the deficit below the government's target, which is Rp956.3 trillion or 6.09\% of GDP. Realisation of state revenue reached Rp1,533.6 trillion or $96.1 \%$ of the target (Perpes 72/2020) and realized state expenditure reached Rp2,589.9 trillion or $94.6 \%$ of the ceiling or grew by $12.2 \%$ from realisation in 2019.

Fiscal policy in 2021 is still expansionary and consolidaative. Based on the state budget posture, central government spending is budgeted at Rp1,954.5 trillion 23 28-Jan-21 out $\mathrm{f}$ a total expenditure of Rp2,750 trillion. Meanwhile, the state revenue is targeted at Rp1,743.6 trillion. The state budget deficit will be reduced to $5.7 \%$ form the maximum limit of $6.34 \%$ of GDP (Perpres 72/2020. In 2020, Indonesia's provisional debt position is estimated at $38.5 \%$ of GDP.

The BI Board of Governors agreed on December 2020 and January 2021 to hold 24 15-Feb-21 the BI-7DRR at $3.75 \%$, while also maintaining the DF and LF rates at $3.00 \%$ and $4.50 \%$.

The BI Board of Governors agreed on the 17th and 18th February 2021 to lower the BI-7DRR by 25 bps to $3.50 \%$, DF rates lowered 25 bps to $2.75 \%$ and $25 \quad 18-F e b-21$ LF rates lowered 25 bps to $4.25 \%$. BI also cotinues to carry out quantitative easing, which is estimated to reach Rp23.81 trillion as of 15th February 2021. Meanwhile, the realisation of the purchase of SBN as a synergy to strengthen NER program has reached Rp40.77 trillion as of 16th February 2021. 


\begin{tabular}{ccc}
\hline No & Date & Announcement \\
\hline & & Until the first quarter of 2021, BI has lowered the BI-7DRR rate by 150 bps \\
& to 3.50\% from 5.00\% in early 2020. BI continues to implement accomodative \\
& monetary policy and synergize with fiscal policy to keep banking and financial \\
& market liquidity conditions remain stable. Realisation of quantitative easing \\
& 18-Mar-21 & In addition, purchases of SBN in the primary market have been realized at \\
& Rp473.42 trillion per 2020 and Rp65.03 trillion as of 16 March 2021. \\
\hline
\end{tabular}

Table A.2.

Malaysia

\begin{tabular}{|c|c|c|}
\hline No & Date & Announcement \\
\hline 1 & 22-Jan-20 & $\begin{array}{l}\text { The Monetary Policy Committee (MPC) of Bank Negara Malaysia decided } \\
\text { to reduce the Overnight Policy Rate (OPR) to } 2.75 \% \text {. The ceiling and floor } \\
\text { rates of corridor of the OPR are corrspondingly reduced to 3.00\% and 2.50\%, } \\
\text { repectively. }\end{array}$ \\
\hline 2 & 24-Feb-20 & $\begin{array}{l}\text { In light of recent developments that are currently unfolding, BNM is closely } \\
\text { monitoring conditions in the financial markets. While ringgit movements } \\
\text { will continue to be market determined, BNM's market operatiosn will ensure } \\
\text { sufficient liquidity and orderly financial market conditions. }\end{array}$ \\
\hline 3 & 27-Feb-20 & $\begin{array}{l}\text { The Government announced the } 2020 \text { Economic Stimulus Package (ESP1) } \\
\text { themed "Bolstering Confidence, Stimulating Growth and Protecting Jobs" and } \\
\text { valued at RM20 billion. The major changes in the policies are as follows: (1) } \\
\text { Deferment of monthly tax instalments for a period of } 6 \text { months for business } \\
\text { in the tourism industry; (2) Revision of monthly tax instalments in the third } \\
\text { month of instalment payment; (3) Tax deductions of up to RM3000,000 on } \\
\text { renovation costs incurred on business premises; (4) Contribution by employees } \\
\text { to Employees Provident Fund is reduced to } 7 \% \text { from } 11 \% \text {. }\end{array}$ \\
\hline 4 & 27-Feb-20 & $\begin{array}{l}\text { To assist business and households impacted by the COVID-19 outbreak, BNM } \\
\text { is allocating RM3.3 billion of financing facilities under BNM's Fund for SMEs } \\
\text { to provide support for SMEs in sustaining business operations, safeguard } \\
\text { jobs and encourage domestic investments. Interested SMEs can access three } \\
\text { financing facilities: (i) Special Relief Facility (SRF), with an allocation of RM2 } \\
\text { billion, is availabble form } 6 \text { March } 2020 \text { to } 31 \text { December 2020; (ii) Agrofood } \\
\text { Facility, with an allocation of RM1 billion, is available from 6 March } 2020 \\
\text { onwards; (iii) SME Automation and Digitalisation Facility (ADF) with } \\
\text { allocation of RM300 million. Financial institutions have also committed to } \\
\text { support affected businesses and households. Financial institutions expect to } \\
\text { approve about RM200 billion of business and home financing to eligible SMEs } \\
\text { and households in 2020. }\end{array}$ \\
\hline 5 & 03-Mar-20 & $\begin{array}{l}\text { The MPC of BNM decided to reduce the OPR by } 25 \text { basis points to } 2.50 \% \text {. The } \\
\text { ceiling and floor rates of the corridor of the OPR are correspondingly reduced } \\
\text { to } 2.75 \% \text { and } 2.25 \% \text {, respectively. }\end{array}$ \\
\hline 6 & 19-Mar-20 & $\begin{array}{l}\text { BNM wishes to announce that the Statutory Reserve Requirement (SRR) Ratio } \\
\text { will be lowered by } 100 \text { basis points from 3.00\% to } 2.00 \% \text { effective } 20 \text { March } \\
\text { 2020. In addition, each Principal Dealer is able to recognise MGS and MGII of } \\
\text { up to RM1 billion as part of the SRR compliance. This flexibility to the Principal } \\
\text { Dealers is available until } 31 \text { March 2021. These combined measures will release } \\
\text { approximately RM30 billion worth of liquidity into the banking system. }\end{array}$ \\
\hline
\end{tabular}




\begin{tabular}{|c|c|c|}
\hline No & Date & Announcement \\
\hline 7 & 25-Mar-20 & $\begin{array}{l}\text { BNM set a number of regulatory and supervisory measures in support of } \\
\text { efforts by banking institutions to asisst individuals, SMEs, and corporttaions to } \\
\text { manage the impact of the Covid-19 outbreak. (1) Deferment and restructuring } \\
\text { of loans/financing facilities to induvidual and SMEs, also to corporations. } \\
\text { Banking institutions will offer a deferment for a period of } 6 \text { months, with effect } \\
\text { from } 1 \text { April 2020. This offer is applicable to performing loans, denominated } \\
\text { in RM, that have not been in arrears for more than } 90 \text { days. For credit card } \\
\text { facilities, banking institutions will offer to convert the outstanding balances } \\
\text { into a 3-yearterm loan with reduced interest rates. (2) Ample liquidity } \\
\text { conditions like on } 19 \text { March } 2021 \text { announcemnet. (3) Last, additional } \\
\text { supervisory and prudential measures: banking institutions will be allowed to } \\
\text { draw down on capital coservation buffer of } 2.5 \% \text {, operate below the minimum } \\
\text { liquidity coverage ratio of } 100 \% \text {, and utilise the regulatory reserves that were } \\
\text { set aside during periods of strong loan growth. }\end{array}$ \\
\hline 8 & 27-Mar-20 & $\begin{array}{l}\text { The Government announced a ESP2 themed "Prihatin Rakyat". ESP2 valued } \\
\text { at RM250 billion, includes: RM128 billion for the protection of Rakyat welfare; } \\
\text { RM100 billion to support SMEs; RM2 billion to strengthen the country's } \\
\text { economy; and RM20 billion to pursue measures announced under ESP1. }\end{array}$ \\
\hline 9 & 27-Mar-20 & $\begin{array}{l}\text { BNM is enhancing the existing financial facilities under the BNM's Fund for } \\
\text { SMEs, and increasing the allocation of the facilities by an additional RM4.0 } \\
\text { billion to RM13.1 billion. The SRF, AF, and ADF policies were announced as } \\
\text { part of the first economic stimulus package on } 27 \text { Feb } 2020 \text {. Since these facilities } \\
\text { available, participating FIs have approved a total of RM119 million of financing } \\
\text { to } 196 \text { SMEs, with an approval rate of } 84 \% \text {. SME can also avail themselves } \\
\text { to Credit Guarantee Corporation Malaysia Berhad's (CGC) BizMula-i and } \\
\text { BIzWanita-i schemes for financing up to RM300,000. }\end{array}$ \\
\hline 10 & 06-Apr-20 & $\begin{array}{l}\text { The Government announced an additional SME ESP3, valued at RM10 billion } \\
\text { that includes: (i) an additional RM7.9 billion for the wage subsidy program; } \\
\text { and (ii) the creation of a RM2.1 billion special prihatin grant for all eligible } \\
\text { SMEs and micro businesses. }\end{array}$ \\
\hline 11 & 05-May-20 & $\begin{array}{l}\text { The MPC of BNM decided to reduce the OPR by } 50 \text { basis points to } 2.00 \% \text {. The } \\
\text { ceiling and floor rates of the corridor of the OPR are correspondingly reduced } \\
\text { to } 2.25 \% \text { and } 1.75 \% \text {, respectively. With this decision, the OPR has been reduced } \\
\text { by a total of } 100 \text { basis points. }\end{array}$ \\
\hline 12 & 07-Jul-20 & $\begin{array}{l}\text { The MPC of BNM decided to reduce the OPR by } 25 \text { basis points to } 1.75 \% \text {. The } \\
\text { ceiling and floor rates of the corridor of the OPR are correspondingly reduced } \\
\text { to } 2.00 \% \text { and } 1.50 \% \text {, respectively. The reduction in the OPR provides additional } \\
\text { policy stimulus to acelerate the pace of economic recovery. }\end{array}$ \\
\hline 13 & 10-Sep-20 & $\begin{array}{l}\text { The MPC of BNM decided to maintain the OPR at } 1.75 \% \text {. The cumulative } 125 \\
\text { basis points reduction in the OPR this year will contine to provide stimulus to } \\
\text { the economy. }\end{array}$ \\
\hline 14 & 23-Sep-20 & $\begin{array}{l}\text { The Government announced the RM10 billion Prihatin Supplementary } \\
\text { Initiative Package (Kita Prihatin) in line with its effort to boost economic } \\
\text { recovery. This additional package includes the RM7 billion Bantuan Prihatin } \\
\text { Nasional (BPN) 2.0, the WSP 2.0 worth RM2.4 billion and Prihatin Special } \\
\text { Grant (GKP) worth RM600 million. }\end{array}$ \\
\hline 15 & 06-Nov-20 & $\begin{array}{l}\text { BNM will establish additional financing facilities to provide relief and support } \\
\text { recovery for SMEs: (i) Establishment of RM2 billion Targeted Relief and } \\
\text { Recovery Facility (TRRF), (ii) Establishment of RM1 billion High Tech Facility } \\
\text { (HTF), (iii) RM110 million increase in allocation for the Micro Enterprises } \\
\text { Facility (MEF). }\end{array}$ \\
\hline
\end{tabular}




\begin{tabular}{|c|c|c|}
\hline No & Date & Announcement \\
\hline 16 & 06-Nov-20 & $\begin{array}{l}\text { Malaysian Government announces largest budget to address Covid-19 impact } \\
\text { and spur economic growth. Spending for } 2021 \text { is forecast at RM322.5 billion, an } \\
\text { increase of around 8.5\% relative to 2020's original budget. The budget rest on } \\
\text { a forecast of } 6.5 \% \text { - 7.5\% GDP growth in } 2021 \text { and estimates the fiscal deficit to } \\
\text { decline to } 5.4 \% \text { - lower than 2020's projected figure. }\end{array}$ \\
\hline 17 & 18-Jan-20 & $\begin{array}{l}\text { In 2020, the Malaysian Government had announced four stimulus packages } \\
\text { worth RM305 billion to keep the engines of the economy running against the } \\
\text { backdrop of a global pandemic. In this 2021, the Government announced the } \\
\text { PERMAI Assistance package worth RM15 billion. }\end{array}$ \\
\hline 18 & 20-Jan-21 & $\begin{array}{l}\text { The MPC of BNM decided to maintain the OPR at } 1.75 \% \text {. BNM is also } \\
\text { announcing the extension of the flexibility for banking institutions to use MGS } \\
\text { and MGII to meet the SRR compliance until } 31 \text { Dec } 2022 \text {. This flexibility which } \\
\text { was previously announced on } 05 \text { May 2020, is currently applicable until } 31 \\
\text { May 2021. The SSR ratio remains unchanged at 2.00\%. Since March 2020, the } \\
\text { reduction inn the SRR ratio by } 100 \text { basis points and flexibility to recognise MGS } \\
\text { and MGII as part of SRR compliance have released approximately RM46 billion } \\
\text { worth og liquidity into the banking system. }\end{array}$ \\
\hline 19 & 05-Feb-21 & $\begin{array}{l}\text { BNM wishes to announce an additional allocation of RM2 billion for the TRRF } \\
\text { and the establishment of a RM200 million Disaster Relief Facility } 2021 .\end{array}$ \\
\hline 20 & 17-Mar-21 & $\begin{array}{l}\text { BNM is pleased to inform that an additional allocation of RM700 million } \\
\text { has been provided for the SME ADF, bringing the facility's total size to RM1 } \\
\text { billion. The ADF aims to encourage SMEs across sectors to automate processes } \\
\text { and digitalise operations to increase productivity and efficiency. }\end{array}$ \\
\hline 21 & 17-Mar-21 & $\begin{array}{l}\text { Malaysia announced a RM20 billion ( } \$ 4.9 \text { billlion) package to revitalize } \\
\text { economic activity as Covid infections slow and vaccines are rolled out. The } \\
\text { plan will include a RM11 billion fiscal injection. Other measures announced } \\
\text { include: (i) discount on electricity bills extended to June 30; (ii) tax breaks on } \\
\text { tourism extended till Dec. 31; (iii) one-time payout of RM500 to the poorest } \\
\text { 40\% (B40); (iv) equity crowdfunding expanded to unlisted companies; (v) a } \\
\text { RM20 million for palm-oil machinery. }\end{array}$ \\
\hline
\end{tabular}

Table A.3.

Singapore

\begin{tabular}{|c|c|c|}
\hline No & Date & Announcement \\
\hline 1 & 18-Feb-20 & $\begin{array}{l}\text { To address the economic uncertainties brought about by the Covid-19, } \\
\text { DPM Heng Swee Keat unveiled a "Unity Budget" to help the city-state. } \\
\text { The S } \$ 4 \text { billion Stabilisation and Support Package aims to help workers } \\
\text { stay employed and also firms with cash flow and operating costs. To help } \\
\text { households weather through these uncertain times, a special } \$ \$ 1.6 \text { bilion } \\
\text { Care and Support Package will also provide timely help for Singaporeans, } \\
\text { with the less well-off receiving more. Additionally, the GST will remain } \\
\text { at 7\% until after 2021. However, with an ageing population and growing } \\
\text { healthcare needs, GST will still need to increase by 2025. A S\$6 billion } \\
\text { Assurance Package will help cushion the impact of the increase on our } \\
\text { daily expenses. Last, a S } \$ 800 \text { million is set to support front-line agencies } \\
\text { fighting Covid-19. }\end{array}$ \\
\hline
\end{tabular}




\begin{tabular}{|c|c|c|}
\hline No & Date & Announcement \\
\hline 2 & 26-Mar-20 & $\begin{array}{l}\text { Known as Resilience Budget, the Supplementary Budget } 2020 \text { includes } \\
\text { revised Government revenue and expenditure plans for the current } \\
\text { financial year. It complements the Unity Budget and addresses the rapidly } \\
\text { evolving Covid-19 situation and the impact on Singapore's economy and } \\
\text { society. A total } \$ \$ 4 \text { billion aims to scrapping of property tax for hard-hit } \\
\text { sectors; wage support for businesses; freezing of government fees; and } \\
\text { fiscal } 2020 \text { deficit estimated } 7.9 \% \text { of GDP. }\end{array}$ \\
\hline 3 & 30-Mar-20 & $\begin{array}{l}\text { MAS will adopt a zero percent }(0 \%) \text { per annum rate of appreciation of } \\
\text { the policy band starting at the prevailing level of the S\$NEER. There will } \\
\text { be no change to the width of the policy band. This policy decision hence } \\
\text { affirms the present of the S\$NEER, as well as the width and zero percent } \\
\text { appreciation slope of the policy band going forward, thus providing } \\
\text { stability to the trade-weighted exchange rate. }\end{array}$ \\
\hline 4 & 21-Apr-20 & $\begin{array}{l}\text { The Singapore Government annouced a third round of support measures } \\
\text { named the Solidarity Budget. A S\$5.1 billion aims for extends wage } \\
\text { subsidies and foreign-worker levy waiver; raises cash handouts; raises } \\
\text { fiscal } 2020 \text { deficit estimate to } 8.9 \% \text { of GDP; and the } 75 \% \text { wage subsidy was } \\
\text { extended to all businesses, foreign-worker levy was waived for May and } \\
\text { S\$750 employer rebate per worker was announced. }\end{array}$ \\
\hline 5 & 26-May-20 & $\begin{array}{l}\text { The Government announced the "Fortitude" Budget. This } \$ \$ 33 \text { billion } \\
\text { Supplementary Budget will provide support for businesses and workers to } \\
\text { adapt, transfor, and seize new opportunities. Extends foreign worker levy } \\
\text { waiver and rebate for two months; extends wage subsidy until August for } \\
\text { some firmsl raises wage support for severely hit sectors to } 50 \% \text { or } 75 \% \text {. }\end{array}$ \\
\hline 6 & 17-Aug-20 & $\begin{array}{l}\text { The Government announced additional support measures of } S \$ 8 \text { billion to } \\
\text { cushion the blow from Covid-19 pandemic, extending wage subsidies and } \\
\text { aiming to shore up the hard-hit aviation and hospitality sectors for } S \$ 187 \\
\text { million. The new set of measures, announced almost three months after the } \\
\text { last package, adds to Singapore's total pledged aid of almost } S \$ 100 \text { billion. } \\
\text { The government now projects a budget deficit of } S \$ 74.2 \text { billion for this } \\
\text { fiscal year. }\end{array}$ \\
\hline 7 & 14-Oct-20 & $\begin{array}{l}\text { MAS will maintain a zero percent per annum rate of appreciation of the } \\
\text { policy band. The width of the policy band and the level at which it is } \\
\text { centred will be unchanged. }\end{array}$ \\
\hline 8 & 16-Feb-21 & $\begin{array}{l}\text { Singapore's government announced its } 2021 \text { national budget where } \\
\text { it allocated } \$ \$ 11 \text { billion for a new fiscal package, named the Covid-19 } \\
\text { Resilience Package, which extends existing schemes to help businesses and } \\
\text { save jobs by subsidizing wages of workers, providing access to working } \\
\text { capital for businesses, and supporting targeted industries like aviation. } \\
\text { The Singapore givernment is expected to draw } \$ \$ 53.7 \text { billion from its } \\
\text { reserves for this year as well as } \$ \$ 24 \text { billion over the next three years to } \\
\text { assist businesses in their transition to a post-pandemic world. Singapore is } \\
\text { expected to record a deficit of } \$ \$ 11 \text { billion in } 2021 \text {. From this, } \$ \$ 4.8 \text { billion is } \\
\text { earmarked for safe reopening measures, such as free vaccinations, contact } \\
\text { tracing, and testing strategies. }\end{array}$ \\
\hline
\end{tabular}


Table A.4.

Thailand

\begin{tabular}{lcc}
\hline No & Date & Announcement \\
\hline 1 & 05-Feb-20 & $\begin{array}{c}\text { The Monetary Policy Committee (MPC) voted unanimously to cut the } \\
\text { policy rate by 0.25 percentage point from 1.25 to } 1.00 \text { percent effective } \\
\text { immediately. }\end{array}$ \\
\hline 04-Mar-20 & $\begin{array}{c}\text { The Thai government issued Phase One of the incentives to counter the } \\
\text { Covid-19 outbreak. The stimulus package, valued at 100 billion baht, } \\
\text { provides assistance for businesses and households in the form of low- } \\
\text { interest loans and cash handouts. }\end{array}$ \\
\hline
\end{tabular}

3 20-Mar-20

The MPC voted unanimously to cut the policy rate by 0.25 percentage point, from 1.00 to 0.75 percent effective on 23 March 2020, to reduce interest burdens of borrowers affected by the outbreak and to alleviate liquidity strain in the financial markets.

The Thai government issued its second stimulus worth 117 billion baht.

This second package focused on enhancing the incentives provided in Phase 1 and extending the filing of tax returns for businesses and employees. SMEs are eligible to receive up to 3 million baht in loans with 4 24-Mar-20 an interest rate set at 3\% (for the first two years of the loan). Workers not covered by the Social Security Fund (SSF) will receive 5,000 baht in cash for the next three months. Workers covered under the SSF program will receive an increased unemployment compensation equivalent to $50 \%$ of salaries. A 10,000 baht emergency loan at a $0.1 \%$ interest rate per person and a 50,000 baht with an interest rate at $0.35 \%$ has been made available.

Additional measures to assist SMEs affected by Covid-19 outbreak and to stabilize the corporate bond market. The package consists of four important measures as follows: (1) A loan payment holiday of 6 months for all SMEs with a credit line not exceeding 100 million baht, to provide the much-needed liquidity to the SMEs; (2) Soft loans to support liquidity

for SMEs with a credit line not exceeding 500 million baht, with a

$5 \quad 07$ April 20 concessional interest rate of $2 \%$ per annum and interest-free for the first 6 months; (3) Market liquidity enhancement to stabilize the corporate bond market. Currently, the total outstanding of Thai corporate bond market is approximately 3.6 trillion baht or more than $20 \%$ of GDP; (4) Reducing the FDIF fee to ease the loan interest burden of businesses and households. The BOT will halve the rate of contribution from financial institutions to the FIDF from $0.46 \%$ of deposit base to $0.23 \%$ per annum for the period of two years.

The Thai government issued its third stimulus package worth 1.9 trillion baht. This latest package is equivalent to $10 \%$ of GDP. 1 trillion baht was provided through bond issuance and 900 billion baht from the Bank of

Thailang (BOT). The package provide 500 billion baht in funding for 6 07-Apr-20 commercial banks to lend to SMEs. 1 trillion baht to help households, from this total, 600 billion baht was alloted to ramp up financial aid to temporary and contract workers, also self-employed persons. The remaining 400 billion will go towards rehabiliting the economy through projects.

The first and second packages of government measures to mitigate the 7 08-Apr-20 impact of the Covid-19 outbreak, totaling 464 billion baht or 2.8 percent of GDP (excluding tax relief measures worth approximately 260 billion baht or $1.5 \%$ of GDP), were mostly measures on credit and transfers.

\begin{tabular}{lcc}
\hline 8 & 20-May-20 & $\begin{array}{r}\text { The MPC voted } 4 \text { to } 3 \text { to cut the policy rate by } 0.25 \text { percentage point from } \\
0.75 \text { to } 0.50 \text { percent effective immediately. }\end{array}$ \\
\hline 9 & 24-Jun-20 & The MPC voted unanimously to maintain the policy rate at 0.50 percent. \\
\hline
\end{tabular}




\begin{tabular}{|c|c|c|}
\hline No & Date & Announcement \\
\hline 10 & 07-Oct-20 & $\begin{array}{c}\text { At the meetings on August } 5 \text { and September } 23,2020 \text {, the MPC voted } \\
\text { unanimously to maintain the policy rate at } 0.50 \text { percent. }\end{array}$ \\
\hline 11 & $16-O c t-20$ & $\begin{array}{l}\text { BOT revealed the following progresses of the measure on loan payment } \\
\text { holiday under the Emergency Decree on Financial Assistance to SMEs } \\
\text { affected by Covid-19 which will end on October 22, 2020. SMEs totaling } \\
1.05 \text { million account have availed themselves of the loan payment holiday } \\
\text { with an outstanding debt of } 1.35 \text { trillion baht. This figre is different from } \\
\text { the } 6.89 \text { trillion baht outstanding debt of SMEs an individual borrowers } \\
\text { which have been assisted by financial relief programs. Specialized Financial } \\
\text { Institutions (SFIs) whose customers account for an outstanding loan of } 400 \\
\text { billion baht, have already deferred payments for 3-6 months. Onl } 6 \% \text { of the } \\
\text { total outstanding debt of } 950 \text { billion baht are cases where banks have not } \\
\text { been able to get in touch or is in the process of contacting their customers. }\end{array}$ \\
\hline 12 & 12-Nov-20 & $\begin{array}{l}\text { Due to the high uncertainty in the near future, the BOT supports the } \\
\text { preventive measures by allowing financial institutions to pay dividends for } \\
\text { the year } 2020 \text { not exceeding last year payout ratio and } 50 \% \text { of this year's net } \\
\text { profit. }\end{array}$ \\
\hline 13 & 06-Jan-21 & $\begin{array}{l}\text { At the meetings on November } 18 \text { and December } 23,2020 \text {, the MPC voted } \\
\text { unanimously to maintain the policy rate at } 0.50 \text { percent to support the } \\
\text { economic recovery which remained highly uncertain. }\end{array}$ \\
\hline 14 & 12-Jan-21 & $\begin{array}{l}\text { On December 21, 2020, the Thailand Board of Investment (BOI) issued its } \\
\text { latest stimulus package to accelerat foreign investments into the country. } \\
\text { This latest package provides additional tax incentives, such as corporate } \\
\text { income tax (CIT) deductions for large-scale project and for businesses } \\
\text { seeking to adopt digital technologies in their operations. Furthermore, } \\
\text { the government has granted the establishment of a new economic zone } \\
\text { to support the development of Thailand's genomic industry. Project in } \\
\text { selected industries with investments worh at least } 1 \text { billion baht will } \\
\text { eligible for a CIT deduction of } 50 \% \text { on profits generated from existing BOI } \\
\text { projects for a period of five years. }\end{array}$ \\
\hline 15 & 03-Feb-21 & $\begin{array}{l}\text { The MPC voted unanimously to maintain the policy rate at } 0.50 \text { percent to } \\
\text { support the economic recovery which remained highly uncertain. }\end{array}$ \\
\hline 16 & 05-Feb-21 & $\begin{array}{l}\text { On January 26, 2021, Thailand's government issued its latest tax relief } \\
\text { package for businesses. This latest package includes the reduction of land } \\
\text { and building tax by } 90 \% \text { for 2021, in addtion to an extending the filing } \\
\text { deadline for personal, value-added, and withholding tax. }\end{array}$ \\
\hline 17 & 24-Mar-21 & $\begin{array}{l}\text { The MPC voted unanimously to maintain the policy rate at } 0.50 \text { percent to } \\
\text { support the economic recovery which remained highly uncertain. }\end{array}$ \\
\hline
\end{tabular}

